\title{
Fasciola hepatica: identificação in situ de antígenos
}

Sandra Márcia Tietz

MARQUES ${ }^{1}$

Maria Lúcia

SCROFERNEKER ${ }^{2}$

Rosiléia M de QUADROS 3

Correspondência para:

SANDRAMÁRCIA TIETZMARQUES

Rua João Mosele, 58 ,

89700-000 - Concórdia-SC

sandra.marques@concordia.psi.br

Recebido para publicação: 23/03/2004 Aprovado para publicação: 13/02/2006

\author{
1 - Escola Agrotécnica Federal de Concórdia, Concórdia, SC \\ 2 - Instituto de Ciências Básicas da Saúde, Universidade Federal do Rio \\ Grande do Sul, RS \\ 3 - Universidade do Planalto Catarinense - Lages, SC
}

\section{Resumo}

Palavras-chave:

Trematódeos.

Fasciola hepatica.

O presente estudo objetivou avaliar antígenos excretórios/secretórios

(Ag E/S) e somáticos (Ag S) de Fasciola hepatica, anticorpos específicos e demonstrar a presença de sítios reativos em corte histológico do parasito adulto pela técnica de imunoistoquímica. A resposta imune foi observada pela reação intensa nas células que circundam a ventosa ventral do parasito. A técnica de imunoistoquímica é sensível e de fácil execução na detecção de sítios antigênicos em cortes histológicos de Fasciola bepatica.

\section{Introdução}

A fasciolose é uma zoonose parasitária de importância econômica para ruminantes, embora outros animais podem também ser infectados; porém, é de menor importância em escala global nestes hospedeiros ${ }^{1}$. O homem também é suscetível e, em algumas áreas do mundo, a fasciolose humana tem caráter epidêmico e é considerada zoonose emergente ${ }^{2}$. No Brasil, os últimos relatos de prevalência mostraram taxas com grande amplitude nas diferentes regiões, desde $6 \%$ até acima de $80 \%{ }^{3,4}$.

Nas doenças parasitárias, a utilização de métodos imunológicos para identificação e localização de sítios antigênicos de parasitos é importante para melhorar as técnicas diagnósticas ajudando no conhecimento destas proteínas e de seus mecanismos, proporcionando rapidez e eficiência na detecção da doença ${ }^{5,6}$. Antígenos de Fasciola bepatica são investigados por métodos imunológicos e propriedades biológicas, auxiliando no entendimento de sua complexidade e localização dentro do parasito $^{7,8,9,10,11,12}$. Algumas investigações têm enfocado a identificação e tipificação molecular de agentes etiológicos, permitindo estabelecer perfis genéticos característicos para melhor compreensão e relação com seus hospedeiros e o meio ambiente ${ }^{13,14} \mathrm{O}$ objetivo deste trabalho foi de determinar a localização histológica de frações antigênicas de Fasciola hepatica, avaliar a antigenicidade de antígenos excretórios/secretórios (Ag E/ $\mathrm{S})$ e somáticos $(\mathrm{Ag} \mathrm{S})$ e anticorpos específicos em corte histológico.

\section{Materiais e Métodos}

\section{Processamento dos parasitos adultos}

Os exemplares adultos de Fasciola hepatica foram obtidos de bovinos abatidos em frigorífico, pela dissecação de fígados. Os parasitos foram retirados, colocados em água destilada e lavados várias vezes a fim de eliminar restos de sangue e bile, foram transportados a $4^{\circ} \mathrm{C} \mathrm{em}$ frascos de vidro. Para a obtenção do antígeno somático, frascos com solução salina estéril receberam, cada um, 20 fascíolas. Para a obtenção do antígeno secretório-excretório, as fascíolas foram mantidas por 24 horas em solução salina estéril acrescida de EDTA ( $5 \mu \mathrm{g} / \mathrm{ml})$, pepstatina A $(2 \mu \mathrm{g} / \mathrm{ml})$ e leupeptina $(2 \mu \mathrm{g} / \mathrm{ml})$.

\section{Produção do antígeno somático (Ag S)}

Lotes de vinte fascíolas foram macerados com pistilo de vidro em cadinho com a adição de $20 \mathrm{ml}$ de solução salina estéril. As amostras foram centrifugadas a 8000 x g por 30 minutos a $4^{\circ} \mathrm{C}$. O sobrenadante foi retirado e dializado contra 
5 volumes de água destilada, "overnight” em geladeira, com a troca da água destilada de 2 em 2 horas. A solução obtida foi fracionada, colocada em frascos com capacidade para $50 \mathrm{ml}$. A dosagem da proteína foi avaliada pela técnica de Bradford ${ }^{15}$. As amostras foram então liofilizadas e armazenadas em congelador até o momento da inoculação.

Produção do antígeno excretório-secretório (Ag E/S)

Cem parasitos foram lavados várias vezes com solução salina estéril. Foram colocados em frasco de vidro esterilizado contendo $400 \mathrm{ml}$ de solução salina estéril acrescida de $2 \mathrm{mg}$ de EDTA, pepstatina A e leupeptina, mantidos por 24 horas em geladeira. A solução foi colocada em tubos e centrifugada a $8000 \mathrm{x}$ g por 30 minutos a $4^{\circ}$ C. A amostra foi colocada em sacos de diálise, dializada contra 5 volumes de água destilada, "overnight", em geladeira, com troca da água destilada de 2 em 2 horas. Foram, então, colocadas em frascos com capacidade de $50 \mathrm{ml}$ e submetidas à dosagem de proteínas pela técnica de Bradford (1976). As amostras foram liofilizadas e armazenadas em congelador até o momento da inoculação.

\section{Inoculação dos coelhos}

Os três coelhos foram colocados em gaiolas individuais. Na primeira semana foi realizado o exame clínico e parasitológico dos animais. O coelho 1 foi inoculado com $0,5 \mathrm{ml}$ de antígeno $\mathrm{E} / \mathrm{S}$ acrescido de $0,5 \mathrm{ml}$ de adjuvante completo de Freund. Foram inoculados $0,25 \mathrm{ml}$, via subcutânea, nas regiões axilar e inguinal. Foram realizadas 5 inoculações, com intervalos semanais. $\mathrm{Na}$ quinta inoculação foi feita uma sangria de prova e na sexta semana foi executada a sangria branca. O coelho 2 foi inoculado com o antígeno somático usando a mesma metodologia. O coelho 3 foi o controle. Após a sangria total, o sangue foi centrifugado, o soro separado, fracionado em porções de $1 \mathrm{ml}$ e mantido em congelador.As amostras de soro foram inativadas a $56^{\circ} \mathrm{C}$ durante 30 minutos para evitar a atividade do complemento.

A preparação histológica dos cortes de Fasciola hepatica adulta foi executada conforme procedimento de López et al. ${ }^{6}$. Os soros hiperimunes e os soros negativos de coelhos, na diluição de 1:100 foram testados em lâminas com cortes histológicos de Fasciola hepatica pela técnica de imunoistoquímica, utilizando-se o Kit DAKO LSAB + Kit Peroxidase (K 0690, CA,USA).

\section{Resultados e discussão}

Resposta imune foi observada pela coloração marrom nas células próximas da ventosa ventral $(\mathrm{Vv})$ e ovários contendo ovos do parasito, demonstrando a antigenicidade das amostras de $\mathrm{Ag} \mathrm{S}$ e E/S analisadas (Figura 1).

Em razão da grande área geográfica do país, as características de ecossistema variam, com diferenciais climatológicos que influenciam na epidemiologia de muitas doenças como a fasciolose e, portanto, de difícil controle. O diagnóstico mais difundido é através do exame coproparasitológico, que apesar de sua economia, nem sempre é vantajoso, pois requer a presença de ovos, dependente do período pré-patente longo, além da demora no tempo de processamento de grande quantidade de amostras, quando se objetiva estudos populacionais ${ }^{16}$.

Nas técnicas imunodiagnósticas, a sensibilidade e especificidade dependem das características da concentração do antígeno e da qualidade do preparado antigênico que se utiliza ${ }^{12,13}$. Os antígenos utilizados neste experimento mostraram reatividade pela técnica imunoistoquímica, como os encontrados por Miranda e Vázquez ${ }^{6}$, possibilitando sua posterior utilização em testes sorológicos.

A localização in situ de epítopos em corte de Fasciola hepatica também foi demonstrada por Hanna e Hillyer ${ }^{17}$ e Lopez et al. ${ }^{5}$, embora estes autores utilizaram soro 


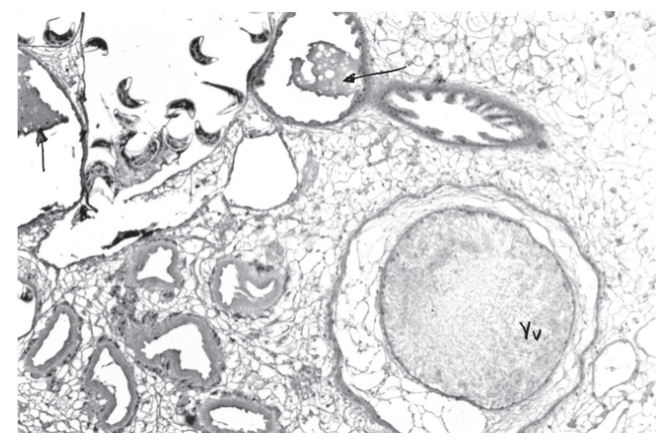

Figura 1 - Localização de antígeno E/S em corte histológico de Fasciola hepatica adulta. Deposição de cromógeno (setas) próximo à ventosa ventral $(\mathrm{Vv})$. 10X de coelhos naturalmente infectados por Fasciola hepatica. A distribuição in situ de antígenos E/S e S de Fasciola hepatica foi demonstrada pela deposição do cromógeno (Figura 1).

\section{Conclusões}

A utilização de antígenos específicos para o diagnóstico apresenta interesse clínico pela facilidade na obtenção e preparação de antígenos desteparasito na rotinalaboratorial, sendo necessário implementar estudos de fracionamento antigênico em técnicas imunológicas de valor diagnóstico.

\section{In situ identification of Fasciola hepatica antigens}

\section{Abstract}

The aim of the present study was to assess excretory-secretory antigens and somatic antigens of Fasciola hepatica, specific antibodies, and to identify reactive sites in histological sections of adult parasites by means of immunohistochemistry. The immune response was observed through the intense reaction of cells that surround the ventral sucker of Fasciola hepatica. Immunohistochemistry is a sensitive and easy-to-use method for detecting antigenic sites in histological sections of this parasite.

\section{Referências}

1 TORGENSON, P.; CLAXTON, J. Epidemiology and control. In: DALTON, J. P. Fasciolosis, 1st ed. New York: Cabi Publishing, 1999. p.113-149.

2 MAS-COMA, S.; BARQUES, M.D.; ESTEBAN, J. G. Human fascioliasis. In: DALTON, J. P. Fascioliasis. 1st ed. New York: Cabi Publishing, 1999. p.411-434

3 IUZ, J. E. et al. Human fascioliasis in the metropolitan area of Curitiba, Brazil. Evaluation of the foci of infection and report of nine cases treated with triclabendazole. Brazilian Journal of Infectious Diseases, v.3, n.6, p.220225,1999 .

4 SERRA-FREIRE, N. M. et al. Reinvestigação sobre a distribuição da Fasciola hepatica no Brasil. A Hora Veterinária, ed. Extra 1: p.19-21,1995.

5 LOPEZ, M. Major Fasciola hepatica antigens are mainly localized within the digestive tube of the adult. Parasitología al Día (FLAP), v. 21, p.104-108, 1997.

6 MIRANDA, E.M.; VÁZQUEZ, Z.G. Aislamiento e identificación in situ de antígenos de Fasciola hepatica. Veterinaria México, v. 25, n. 3, p. 267-271, 1994.

7 CERVI, L. A.; RUBINSTEIN, H.; MASIH, D. T. Serological, electrophoretic and biological properties of Fasciola hepatica antigens. Revista do Instituto de
Key-words:

Trematode.

Fasciola hepatica. Immunohistochemistry. Antigens.
Medicina Tropical de São Paulo, v. 34, n. 6, p. 517 525, 1992.

8 ESPINO, A. M. et al. Identification and isolation of common antigens of Fasciola hepatica. Revista Cubana de Medicina Tropical, v. 45, n. 1, p. 20-26, 1993.

9 SHAKER, Z. A. et al. Purification and characterization of a specific Fasciola antigen. Journal of the Egyptian Society of Parasitology, v.24, n.2, p.309-316, 1994.

10 TAILLIEZ, R.; KORACH, S. Les antigènes de Fasciola hepatica. II. Étude immunologique et localization in situ d'un antigène spécifique du genre. Annales de I'Institut Pasteur, v. 118, p. 330-339, 1970.

11 TAKYOSHI, M.; INOVE, T.; IWATA, H. Streptavidinreactive protein in Fasciola hepatica. Veterinary Parasitology, v. 58, n. 3, p. 255-261, 1995.

12 VARGAS, D. et al. Implementation of an ELISA-Test for the diagnosis in human hydatid disease. Research and Review in Parasitology, n. 55, p. 223-226, 1995.

13 VARGAS, D. et al. Implementación de un ensayo de ELISA para el diagnóstico de la fascioliasis equina. Boletín Chileno de Parasitología., v. 57, n. 3-4, p. 91-94, 2001.

14 VARGAS, D.; VEGA, M.; GONZÁLEZ, C.M. Aproximación a una caracterización molecular de Fasciola hepatica por la tecnica RAPDs-PCR. Parasitología Latinoamericana, v. 58, p. 11-16, 2003 
15 BRADFORD, M. A rapid and sensitive method for microgram quantities of protein utilizing the principle of protein-dye binding. Analytical Biochemistry, v. 72, p.245-248, 1976.

16 GORMAN, T. Inmunodiagnóstico de la fasciolosis anima. Parasitología al Día, n.15, p. 37-42, 1991.

17 HANNA, R.; HILLYER, G. Fasciola hepatica and Schistosoma mansoni : immunofluorescent antigen localization and cross reactivity. Experimental Parasitology, n. 57, p.1-14, 1984. 